\title{
Transactional and Transformational Leadership: A Comparative Study of the Difference between Tony Fernandes (Airasia) and Idris Jala (Malaysia Airlines) Leadership Styles from 2005-2009
}

\author{
Arif Kamisan, $\mathrm{P}^{1}$ \& Brian E. M. King ${ }^{1}$ \\ ${ }^{1}$ School of Hotel and Tourism Management, The Hong Kong Polytechnic University, Hong Kong, China \\ Correspondence: Arif Kamisan, P, School of Hotel and Tourism Management, The Hong Kong Polytechnic \\ University, 17, Science Museum Road, East Tsim Sha Tsui, Kowloon, Hong Kong. Tel: 852-3400-2645. E-mail: \\ 11555000G@connect.polyu.hk
}

Received: May 27, 2013

Accepted: October 8, $2013 \quad$ Online Published: November 20, 2013

doi:10.5539/ijbm.v8n24p107

URL: http://dx.doi.org/10.5539/ijbm.v8n24p107

\begin{abstract}
Leadership plays an essential role in the success of managing organisation. The purpose of this paper is to examine the leadership styles of two leaders in managing the two biggest airline companies in Malaysia namely, Malaysia Airlines and AirAsia. The results showed that the strong leadership style and approach by the two have contributed to the success of the mentioned airlines. The transactional and transformational approaches have significantly given impact in managing the organisation in the current competitive business environment. Other leadership constructs such as entrepreneurial, ethical, innovative and creative have emerged from the two key leaders in this study and require further discussion in the future. Furthermore, this study managed to provide some insight and perspective of the qualities much needed by the current leadership scene.
\end{abstract}

Keywords: airlines industry, leadership styles, transactional leadership, transformational leadership

\section{Introduction}

Leadership in organisation is a very critical phenomenon as the leader has a substantial amount of responsibility to lead the direction and create good organisational culture. The topic of leadership has become a very popular issue and has gained the attention of many researchers to investigate the issues of leadership in various contexts. For instance, leadership styles in organization (Avolio \& Bass, 2004; Yukl, 1989; Moore \& Rudd, 2006; Northouse, 2004). Naipul \& Wang (2009) reported on entrepreneurship and leadership; leadership and culture (Schein, 2004) and transparent leadership (Salvation, 2006). More recently however, many researchers have investigated the transactional and transformational leadership as a topic of leadership style (Bass, 1990; Avolio \& Bass, 2004; Gill et al, 2008; Kuhnert \& Lewis, 1987; Tracey \& Hinkin, 1994; Atkinson \& Pilgreen, 2011).

Leaders are always seen as strong figures and examples to the employees. Therefore, leaders who carry good leadership characteristics will benefit the organisation and become an icon within the team. In the early study of leadership, Barnard (1938) defined leadership as the ability of a superior to influence the behaviour of subordinates and persuade them to follow a particular course of action. Similarly, Nahavandi (2009) defined the leader as a person who influences individuals and groups within an organisation as well as motivates them to achieve their goals. Meanwhile, Peter Northhouse (2001) defined leadership as a process whereby one individual influences a group of individuals to achieve a common goal. The leader is someone who sets the tone of the organisation, defines its values, norms and creates plus maintains a persona of what the organisation is about (David \& Ricky, 2006). Therefore, leaders have a powerful influence in the organisation and on employees (Yukl, 1989). Someone who has a strong motivation and greatest incentive to move or be more concerned with his own interest rather than others; has a strong personality or temperament and being the most talkative person; likes to dominate over others; and having special knowledge or expertise; often emerge as leaders of groups of people (King, Johnson \& Vugt, 2009).

The topic of leadership has been extensively studied by numerous researchers. It covers many aspects of leadership such as leadership style, traits, factors, etc. Leadership style is a very interesting topic as it affects the success of a particular country, company, group, etc. There have been many leadership theories that have evolved over time and that leadership style has evolved due to the need of adaptation of the situation. As such, 
over the years, many leadership theories have emerged; the Great Man theory; Trait theory; Behavioural theory; Participative leadership theory; Situational leadership theory; Contingency theory; Transactional theory; Transformational theory, etc.

The early Great Man theory and Trait theory made the assumptions that people who are born inheriting positive traits such as intelligence, confidence, visionary, ambitious, charismatic, etc. often makes them successful leaders. Most studies during these periods were more concentrated to focus on personality of successful leaders. Behavioural theories however, make assumptions that leaders can be made or trained thus, the skill be acquired either through training or observation. These theories were then argued and two more popular theories emerged to support the Behavioural theories; Blake \& Mouton Managerial Grid Theory and McGregor's Theory X \& Theory Y. Participative Leadership theory explored the angle whereby leaders encouraged participation and contribution from group members in making decisions. On the other hand, the Contingency theory and Situational Leadership theory focused on the particular variable that dictates the best leadership style based on a particular situation. According to this theory, no leadership style is best in all situations as good leaders should be wise enough to choose the best approach in managing and handling team members. Hence, to be an effective leader, the leader should be very aware adapting and finding the best approach to any situation (Nahavandi, 2009).

\section{Transactional and Transformational Leadership}

The Transactional Leadership theory which is also known as Managerial Leadership became famous in the early 1980s. This theory was concerned about a reward and punishment system in leadership whereby the leader has the power to manipulate the followers in exchange of something of value (Bass, 1990; Burns, 1978; Kuhnert \& Lewis, 1987; Yukl, 1989). It is based on bureaucratic authority and legitimacy within the organisation (Tracey \& Hinkin, 1994). However, the theory works best in several assumptions namely; the highly structural organisation, employees are motivated by rewards, high tendency for guidance and monitoring among the followers. In other words, transactional leaders negotiate to followers what objectives are required to be achieved by the company. They negotiate the conditions either by providing rewards for accomplishing the objectives or threats of punishment for poor performance e.g. cut the bonus and suspension of promotion (Moore \& Rudd, 2006; Bass, 1990).

Further investigation on Transactional Leadership by Avolio \& Bass (2004) described to consist of three factors namely; contingent reward leadership, management by exception (active) and management by exception (passive) which is simplified in Figure 1. Contingent Reward Leadership is a constructive transaction whereby the leaders reward the employees based upon their success and employees punished if they failed to perform. With the agreement made between the leader and employees to fulfil promises to reward the employees with promotions and incentives; it allows the transactional leaders to achieve the desired objective (Bass, 1990). This theory has been considered as quite controversial as it is more like an army command and has a degree of dictatorship in leadership. Management by exception (active) refers to the leaders who monitor followers' performance and take corrective action to ensure the standards are met. Meanwhile, management by exception (passive) is where leaders will intervene only when there is a diversion in the standard and mistakes have occurred. In some cases, the transactional leadership construct divides the gap between the leader and the employees making the leader not having the freedom to interact and communicate with the employees.

The new and popular emerging leadership theory is the Transformational Leadership which seems to be the ideal theory of leadership in the current situation. This is due to the concern on values of the interaction between the leader and the employees as a strong team. The theory makes an assumption that leaders inspire the team with vision and give the direction by motivating and encouraging the subordinates to achieve the organisational goals (Bass, 1990; Avolio \& Bass, 2004; Kuhnert \& Lewis, 1987; Tracey \& Hinkin, 1994).

Further on that, Avolio \& Bass (2004) and Northhouse (2004) classified the four dimensions in Transformational Leadership which are illustrated in Figure 1 on the right side of the model. Firstly, idealised influence and charisma stresses on the ability of the leaders to influence their followers to accept change. Leaders should be able to demonstrate the high moral and ethical behaviour and set a good example before their followers as well as provide the clear vision and mission to them. The second quality is inspirational motivation meaning the ability of the Transformational leader to inspire and motivate the followers to the direction and vision set by the leaders. The third quality is intellectual simulation whereby the Transformational leader stimulates innovation and creativity among the followers. The leaders value and appreciate the contribution of new ideas by the followers for the benefit of the organisation. Lastly, individualised consideration; in this 
context the Transformational leaders value the differences of all the followers and possibly consider different consideration for each employee (Avolio \& Bass, 2004; Moore \& Rudd, 2006; Bass, 1990).

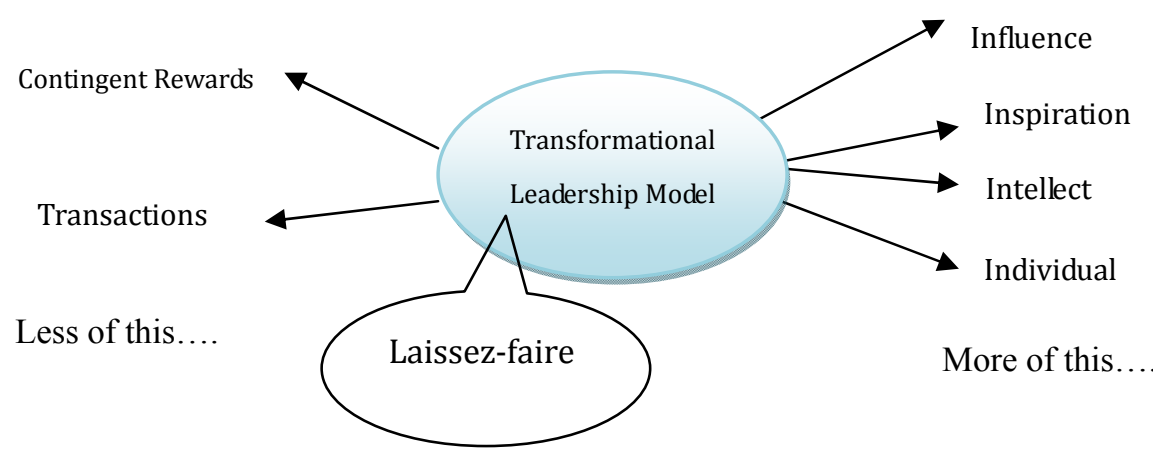

Figure 1. Simple model of transformational vs. transactional leadership based on Bass (1990)

In summary, the model tries to demonstrate that Transformational Leadership should focus and enhance the elements of idealised influence, inspirational motivation, intellectual stimulation and individual consideration which focus on the humanistic approach in leadership. The model also emphasises the factors of Transactional leadership that needs to be slowly diminished in order to strengthen the leadership team in practice.

The main objective of this study is to make a comparative analysis on leadership of two personalities who have headed the biggest airlines in Malaysia namely; Malaysia Airlines and AirAsia. The analysis is from the period of 2005- 2009 when both airlines were struggling to overcome the global financial crisis in 2008 and how the leadership qualities in both leaders have impacted the survival of the organisation they led.

\section{Airlines Industry in Malaysia}

The origin of airlines industry in Malaysia began in 1937, with the formation of Malayan Airways Limited (MAL) through a joint venture between Ocean Steamship Company of Liverpool, the Straits Steamship of Singapore and Imperial Airways to run an air service between Singapore to Penang. However, the first commercial flight only took to the skies in 1947 with the first passenger service from Singapore to Kuala Lumpur (Man \& Justine, 2005; Malaysia Airlines, 2013). With the formation of Malaysia in 1963, the airline changed its name to Malaysia Airlines Limited (MAL) and the airline subsequently grew stronger. However in 1965, despite the separation of Singapore from Malaysia, the airline changed its name again to Malaysia Singapore Airlines (MSA) as a bi-national airline. Nonetheless, the partnership finally parted ways after both countries decided to form their own national airline carriers. The airline was then rebranded as Malaysia Airlines System (MAS) in 1972 and few years later changed to its current name as Malaysia Airlines (Malaysia Airlines, 2013; Ismail, 2010). The national carrier has performed well and achieved much international recognition for the excellent service and performance. The airline has won several international recognitions such as the; World's Best Cabin Crew Award, World's Best Economy Class Award, 5-star Airline Award and the World's Leading Airline to Asia by Skytrax UK as well as by World Travel Award.

The emergence of low cost budget airlines in the last few years has opened a new dimension in passenger demand of the airlines industry especially after the major world economic crisis in 2008 / 2009 (Wong \& Musa, 2011). The success of low cost business model introduced by Southwest Airlines in the early 1970s has motivated other low cost airline companies to join the airlines industry (Wong \& Musa, 2011; Sarker et al, 2012). Therefore in the ASEAN region, there are many low cost airlines that have emerged in the market such as Firefly, AirAsia (Malaysia); Cebu Pacific, Zest Airways (Philippines); Jetstar Airways, Tiger Airways (Singapore); Nok Air, Orient Thai Airlines (Thailand); Malindo Air, Citilink, Lion Air, Mandala Airlines (Indonesia) and Air Mekong (Vietnam). Among the biggest factors on the emergence of the low cost airlines within the region is the liberation and regulation of aviation industry within these regions. The gap in the low cost market segment in the Malaysia market has inspired Tony Fernandes to introduce no frills discounted fares in 2001 which gave a big impact on the demand of low cost airlines in Malaysia and established the brand of AirAsia internationally.

As for now, the airlines industry in Malaysia is dominated by two major airlines namely; Malaysia Airlines and AirAsia with several other small airline companies (Zainol \& Romle, 2007). Malaysia Airlines being the national carrier has been fully classified as a full service airline serving local and international routes across 100 
destinations worldwide (O'Connell \& William, 2005). On the other hand, AirAsia is considered as a low cost budget airline since it was first established in 1993 and began its first flight in 1996. It currently serves domestic as well as international routes in over 75 destinations worldwide in 21 countries (Man \& Justine, 2005). AirAsia has gained a good reputation since it was voted as World Best Low Cost Airlines Award by Skytrax World Airlines Award in 2009 and 2010 respectively.

\section{Methodology}

The methodology employed in the study involves secondary data due to limited time constraints to do field work study and also the financial limitation involved. Hakim (1982 cited by Finn et al, 2000) agreed that secondary data allows the researcher to think more closely about the theoretical aims and substantive issues of the study instead of spending most of the time thinking about the problem of collecting new data. Hence for this research, the study takes on a qualitative technique while a collection of interviews from published written materials, magazines, newspapers and social media has been analysed using content analysis. Hoslti (1968) defined content analysis as any technique for making inferences systematically and objectively whereby data were categorised, assessed and evaluated to derive findings and conclusion. Several recorded materials and documents related to the two personalities have also been analysed and re-analysed for reliability check. These included copies of interviews of the two respective leaders which were published in reports, press releases, newspapers, videos and other public documents made available. The interviews were transcripted, coded and analysed. The topic on leadership and leadership style was the key in identifying the focus of the study. Similarly, several printed interviews of the two leaders were also analysed and translated pertaining the meaning of the leadership.

\section{Leaders' Background}

The primary objective of this study is to analyse and make a comparison of leadership styles of two leaders of the two biggest airlines in Malaysia namely; Dato' Sri Tony Fernandes (Tony Fernandes) and Dato' Sri Idris Jala (Idris Jala).

Table 1. Comparison of Leaders' Background

\begin{tabular}{ccc}
\hline & Tony Fernandes & Idris Jala \\
\hline Date of Birth & 30th April 1964 & 21th August 1958 \\
Age & 49 & 53 \\
Ethnic & Indian Eurasian (Melaka) & Kelabit Indigenous (Sarawak) \\
Education & London School of Economics, 1987 & Masters, Warwick University \\
Nationality & Malaysian & Malaysian \\
\hline
\end{tabular}

\subsection{Background of Tony Fernandes}

Tony Fernandes was born on 30 April 1964 in Kuala Lumpur to an Indian father who was originally from Chennai, India and a Christian Eurasian mother of mixed Portuguese and Malaccan descent. He was educated at Epsom College from 1977 to 1983 and graduated from London School of Economics in 1987. He had worked briefly with Virgin Atlantic as a Financial Controller. He was also the youngest CEO to lead the Warner Music Records (Malaysia) before deciding to set up Tune Air Sdn. Bhd. and ventured into the airlines business.

Fernandes' initial intention during his meeting with the then Prime Minister, Tun Dr. Mahathir Mohamad, in June 2001 was to get the prime minister's official endorsement to become a new operator in the Malaysian aviation industry (Ismail, 2010). At the time of the meeting, Fernandes had already registered a company called Tune Air Sdn. Bhd. in Kuala Lumpur with three other partners. Instead of issuing a new license, Mahathir suggested that Tune Air could acquire an airline by taking over the ailing AirAsia, a sister airline of Malaysia's national carrier, Malaysia Airlines, that was set up to cater flying domestic routes not serviced by the national carrier. Mahathir felt that the needs of the Government and Fernandes' ambition were deemed to be suitable and a good match at the time.

Fernandes had reinvented and remodelled AirAsia based on the highly successful Irish budget airline, Ryannair. It targeted millions of Asians who had never flown and wanted inexpensive basic transportation, fitting well with its slogan of "Now everyone can fly". As a Low-Cost Carrier, AirAsia imposed major cost-cutting measures such as using a single type of aircraft, online and paperless ticketing to eliminate travel agents 
commission, charging for in-flight meals and seating, reducing turnaround time on the ground and ensuring frequent flights. By the year ended $30^{\text {th }}$ June 2006, AirAsia had served 65 cities and carried 9.3 million passengers (Ismail, 2010). Fernandes is now running a profitable enterprise, a remarkable revival of the loss making state-owned enterprise that he took over from the Malaysian Government.

\subsection{Leadership Style}

Tony Fernandes' foresight and vision has turned AirAsia to become one of the well known airline brands in the world. Many observers have attributed the success of AirAsia due to the strong leadership of Tony Fernandes. He was able to create good organisational culture and stressed the importance of working as a team. As the leader in a big organisation which has 10,000 employees, he is easily approachable and accessible to all his staff. Schien (2004) noted in his study that organisation leaders play a key role of establishing an organisational culture that articulated the behaviours, rules and values critical to the achievement of an organisation's mission and strategies. There is no bureaucracy involved in his office and all employees are free to access his office if there is anything important to be discussed and needed an urgent solution (DesiAnwar, 2013; Sutha, 2012; bfmvdo, 2012; Siva, 2009). As what he believes in the current business scenario where business has become much more competitive therefore, having too much bureaucracy could impede the growth of the business. The work culture in AirAsia introduced by Tony Fernandes has made a big impact on the growth of the organisation as the employees were very happy to move forward in the same direction. Employees have been treated as family hence, they feel very proud to be part of the team. Any contribution of ideas for the benefit of the organisation is well accepted and the management rewards these outstanding ideas. Tony Fernandes' leadership stresses the importance of good interaction among all the staff as he maintains a non-hierarchy practice in the office. The internal integration within the organisation articulates the good working environment (Schein, 2004). For such a good leadership practice, he has gained trust and respect among his dedicated employees (Tracey \& Hinkin, 1994).

\subsection{Background of Idris Jala}

Idris Jala who is from the Kelabit indigenous tribe was born in August, 1958, in a small village in the remote area called Bario in Sarawak, East Malaysia. He holds a Masters degree from Warwick University, UK and is currently Malaysia's Minister without Portfolio in the Prime Minister's Department and Chief Executive Officer (CEO) of the Government's Performance Management and Delivery Unit (Pemandu). Currently he sits in Dewan Negara, the Upper House of Malaysia's Parliament as a Senator.

He began his career working for SHELL, an international oil and gas company for quite a long time (23 years) and spent time working abroad in the United Kingdom, the Netherlands and Sri Lanka. When in SHELL, he did quite a lot of work doing turnaround and transformation exercises. In 2005, the Malaysian Government asked him to become the CEO of Malaysia Airlines (MAS) when MAS had its biggest loss in its corporate history. He turned around MAS so fast that in the first year, they managed to break even and in the second year, making record profit. In May 2008, he appeared on national television announcing MAS' first ever 'zero fare' for domestic and a selection of international flights, likened to copying AirAsia's promotional style. This move raised spat between him and AirAsia's boss, Tony Fernandes to a new level.

\subsection{Leadership Style}

Coming from a strong corporate background, Idris Jala had been chosen by the Government of Malaysia to lead the ill fated national carrier during that time. He was appointed as MAS' Chief Executive Officer (CEO)/ Managing Director starting from December $1^{\text {st }}, 2005$ under a contractual agreement of three years. His appointment as the CEO of MAS caused quite a stir in the nation because he did not come from the aviation background. His appointment was merely to save the national carrier from further massive loss and financial crisis. He took up the challenge and successfully turned the losses into profit within the second year he took over the helm of MAS. While serving with SHELL, he was known as 'Mr. Fix-it' as he was responsible for turning around many departments with organisational problems. As quoted in the interview by Dichter et al, 2008.

"The Shell leadership told me to if I couldn't fix it in two years, just tell them and they would shut it down. I'd be the last person to switch off the lights."

\section{Idris Jala}

Before joining Malaysia Airlines, he was known for his expertise in turnaround to transformation strategy. Using his expertise in Profit \& Loss "doctoring", he planned the strategy in order to help the ill fated Government owned airlines from going bankrupt. 


\section{Comparative Analysis on Leadership}

Idris Jala uses pertinent management principles in his daily working life such as the game of the impossible i.e. by setting targets that you yourself feel you cannot do such that you continuously have to battle the fear of failure. He shared his leadership qualities as he described in the interview (Dichter et al, 2008) by saying:

"The leader is like someone who cuts a clearing in a very dense tropical jungle. Everyone else is under the canopy, where they can't see the sky and it's very depressing. The leader has to bring people over to that clearing, into the space where innovation begins. The single biggest thing a leader brings to a turnaround is hope."

Idris Jala

Moreover, he believes in the discipline of action meaning that leaders should be action-oriented, not just simply continuing talking about it and never getting it done. He sees the importance of situational leadership as per Ken Blanchard's models which stated that when you start on a journey of transformation in the beginning, the leadership style must be quite directive in approach so as to get input from the people. When people begin to know how to do it, they become more competent and when they know how to do it, they resolve the problems (Deepa, 2010; Ionindes, 2008). This is supported by the transactional leadership construct which clearly mentioned the management by exception in a way for leaders to monitor the situation. By this point, there has to be a change of style when we must start to empower the people. The principle is to win coalition, getting everyone involved to be part of the whole team and working together with a united objective. Lastly, he believes in divine intervention and understanding humility and vulnerability that makes people do their job on basic principles. As long as we do the best in our jobs, somehow or rather God will reward us even though there is no guarantee things will happen the way they do. He has truly embedded the concept of transactional leadership in the first period of his tenure as a leader in Malaysia Airlines to give the clear direction following his aspiration and mission in executioning the turnaround plan.

From the leadership style context of view, he seemed to be able to adapt the situational leadership construct and transactional leadership style in the organisation. As Idris Jala's appointment as the CEO was to save further losses in Malaysia Airlines, he had a heavy responsibility to save the company form going bankrupt and the future of the employees relied heavily on him. There were two strong conditions during that period that were applicable for Idris Jala to use transactional leadership in a highly structural organisation and with high tendency for guidance and monitoring among the employees. Two out of three conditions have been strongly supported in the transactional leadership construct. He had the strong advantage of being an outsider to make the transformation in Malaysia Airlines. As the employees understood the mission and objectives manifested by the leader, slowly Idris Jala changed his leadership style into Transformational Leadership by emphasising more attention on four dimensions- namely; influence, intellect, inspiration and individual as clearly explained in Bass' Simple Framework model in Figure 1.

In this case, Idris Jala successfully brought some impact to the organisation due to the fact that he was the newcomer from outside the organisation who came in to bring 'new blood' and produced radical changes in the organisation. However, the changes that he tried to make could not go as smoothly as he wanted due to the corporate culture, office politics and the hierarchical working environment having been too long in place for him to make a dent. As such, being the new leader, he found it hard to establish relationships with employees who are unwilling to accept the changes.

On leadership philosophy, Tony Fernandes is known to be a leader who believes in openness. He does not believe in hierarchical structure. Believing in talents within the organisation and inspiring employees to achieve their dream as he believes everybody have their own dreams just like him. He strongly believes in teamwork and treats all his employees as 'Allstars'.

Hence in one of the interviews by Harvey, (2012) the founder of AirAsia, Tony Fernandes, was quoted by saying this.

"In AirAsia, we consider ourselves basically a dream factory. We deliberately decided that we wanted a company where people can pursue their passion and we wanted to make use of all the talent that we have in-house. The culture that we have stems from the fact we want openness and we want people to be creative and passionate about what they do. In order to do that, we've got to inspire them."

Tony Fernandes

Ironically, Tony Fernandes has a slightly different approach in managing AirAsia; he seems to use a more transformational approach which emphasises the importance of having a good relationship with his employees. 
This could be supported by analysing his statement in most of the interviews (DesiAnwar, 2012, bfmvdo, 2012; Harvey, 2012; Sutha, 2012) where he mentioned several aspects of transformational dimensions. Hence, his transformational leadership qualities were contributed by his charisma, intellectual simulation, individualized consideration, idealised influence and inspirational leadership in every action he takes.

In discussing further the leadership among the two leaders, several other themes have emerged as a foundation for further discussion as follows.

\subsection{Technology \& Innovative Leadership}

Another construct that emerged from the analysis is innovation leadership. Innovation leadership in this context refers to the ability of the leader to influence and motivate the followers to produce creative ideas, products, services and solutions within the organisation. In this regard, Tony Fernandes has shown a good example as an innovator with many brilliant ideas and innovative business strategies. For instance, his innovative ways in introducing no-frills airlines, 'zero' fare strategy and famous tagline 'Now everyone can fly' have become the competitive business strategy for AirAsia. As a leader, he utilized technology in its business operations. Similarly, Idris Jala had also innovated several new ideas in Malaysia Airlines, for instance he introduced the idea of "MH" as 'Malaysian Hospitality' in 2007 instead of just being the airlines code referring to Malaysian Airlines. Such a simple idea introduced by him has given the added values of best hospitality service synonym in what Malaysia Airlines provides.

Interestingly, both leaders are aware about the usage of social media as part of business communication. Perhaps, the nature of the workforce industry currently dominated by Generation Y has inspired both leaders to use social media as a means for communication. Studies believed that demographic attributes such as gender, age, etc. influence social dynamics which in turn influence various organisational outcomes such as conflict and turnover, culture, power distribution, innovation, adaptability and organizational performance (Pfeffer, 1983). Tony Fernandes and Idris Jala actively used social media such as twitter, blogs, Facebook, etc. to interact with employees as well as attending to customers' feedback. Both reflected as an open leader with concerns on the importance of technology to carry themselves as a leader serving the people in the new millennium.

The younger generations seem to be more fast-paced and intense in their exercise of leadership and are more open to risk. They tend to be perceived as operating with more energy, intensity and passion while older generations are more likely to maintain a calmer, low-key, understated stance with more emphasis on interpersonal impact. The younger generations are accustomed to a world of immediate access, instant feedback and rapid outcomes compared to the older generation's steady paced progression. As such, they seem to be more demanding for immediacy of outcomes and this often manifests as impatience or abruptness in leadership. The younger generations are more competitive, ambitious and results driven, more self-assured and more opportunistic. Air Asia is a good example of practicing a flatter structural organisation as it attracts and understands the needs of Generation $\mathrm{Y}$ and contradicts with the hierarchy organisation structure in Malaysia Airlines. As such, the younger generations are more likely to respect and also to exercise leadership based on capability, competency and expertise rather than rank.

\subsection{Ethical \& Trust Leadership}

In today's society, the issue of ethics, trust and integrity is becoming a great challenge among leaders. As the world becomes small with the emerging of internet technology and inventions of many social media such as Facebook, twitter, etc. it has globalised the communication hence, the transparency of leadership is needed in order to gain trust from the followers (Tracey \& Hinkin, 1994; Gill et al, 2010). This clearly supports one of the dimensions in transformational construct which idealised influence and charisma. It further explains that leaders could demonstrate high moral and ethical behaviours to their followers to establish the trust. Both the leaders seem to be very active in using social media as part of communication. Tony Fernandes mentioned that as a leader he believes in transparency in managing the organisation. This was supported by his interview with DesiAnwar (2012)'

\section{“.... like transparency, I like openness, I like the staff to know everything then there is no secret......."}

Tony Fernandes

In this sense, Tony Fernandes demonstrates his integrity by practicing what he preaches. He shares the concept of openness in the organisation and on his part, he can be easily approached by any employees at any time and he can sometimes be seen working on the ground and communicating openly. This is warmly accepted by everyone working in AirAsia and he is the leader who 'leads by example'. The charismatic leadership as 
demonstrated by Tony and Idris Jala has gained trust and respect from among the employees and this is truly supported by transformational leadership construct (Nahavandi, 2009)

\subsection{Entrepreneurial Leadership}

Both leaders presented entrepreneur leadership skills although in different capacities. Analyzing the background of Tony Fernandes, he learned his entrepreneur skills from his mother as quoted in an interview (DesiAnwar,2012)

"My mom was selling Tupperware and she teaches me on people, she was an amazing motivator to people and in the organization the biggest asset is the people".

Tony Fernandes

Analysing from the entrepreneur's point of view, Tony Fernandes' successful leadership success is contributed by the strong desire to achieve his dream. He is willing to take high risks and is always positive in achieving his dream. His persistent attitude and dreaming the impossible is truly reflecting the entrepreneurial leadership that is inherent in him. He is a leader with a genuine entrepreneurial DNA and has made his name as a big household name in the budget airlines industry. Although his background was from the entertainment industry, the same capacity and role as a key person in Warner Music has brought him the desire to be successful in the business world.

In a similar case with Idris Jala, he does not come from the airline industry and what he has is the experience of working in the oil and gas conglomerate, SHELL. However, his experience as a leader within SHELL has provided him with the expertise required to lead Malaysia Airlines. For instance, in a major exercise of turnaround strategy of Malaysia Airlines, Idris Jala had come out with a few strategies to raise the profit for the airlines as well as to save from any more major losses. He made some drastic changes such as scrapping unprofitable routes, selling unprofitable assets, etc. In this case, he applied the quality of entrepreneurial spirit into the organisation to ensure the company would remain strong for the future.

\section{Discussion}

It is a very interesting fact that both leaders have vast experience and their role as a leader working in the international arena in various industries. Having international exposure has become the milestone for their career and influenced their leadership style.

The key strength for Tony Fernandes is that he is a genuine leader with very strong entrepreneurial skills. He has demonstrated good leadership and innovative entrepreneurial qualities in leading AirAsia.

Despite the short tenure Idris Jala has had in managing Malaysia's national carrier, he has proven to be very successful. However soon after he left Malaysia Airlines, the new CEO found it very hard to maintain the same strategy as what Idris Jala did in transforming the ill fated airlines to gain profit within a few years after he took over the helm. The question is why such a brilliant leader who has a good track record was not asked to remain long in the company.

In the Malaysia Airlines context, the situation is a bit complex as there are many stakeholders involved such as government, public interest, etc. Therefore, any leader of the national carrier always has to refer to the government for any major decision making that will have a major implication particularly on public interest. It is noted that one of the key success factors of the transformation is the leaders behind the helm of the company (Man \& Justine, 2005). The CEO of Air Asia, Tony Fernandes has created a positive corporate culture within AirAsia. As such, AirAsia will remain strong as long as they keep focusing on cost leadership in their business model as their key sustainability strategy.

The biggest challenges for managing the government linked airline are the interference of many stakeholders and the bureaucracy involved in crucial decision making in Malaysia Airlines. Comparing to AirAsia, the organisational structure is very flat and has less bureaucracy which means less interference for the leaders to make crucial decisions. Another challenge is the internal office politics within Malaysia Airlines and the Workers Union. The previous record has shown that leadership in Malaysia Airlines was led by the top management within Malaysia Airlines staff as they believe that people who lead airlines organisations such Malaysia Airlines should have a strong background about the industry. However, Idris Jala has proven that sometimes leaders not from within the industry can become good leaders as well.

After Idris Jala left the national carrier to take a higher post in the Government, the leadership has been taken up by someone else within the organisation. However, the future of the national carrier was no longer as successful as during Idris Jala's time. The national carrier incurred losses again in 2011 mainly due to the rise in fuel prices. 
It seemed that the change of leadership has turned MAS to struggle again in the market while AirAsia under Tony Fernandes continues to expand successfully and ready to soar further into the skies.

\section{Conclusion}

In conclusion, leadership plays a significant role in impacting the success of an organisation. The ability of the leaders to apply the transactional and transformational approach has proven to be a good approach in managing the companies they lead. This paper focuses on the two leaders, Tony Fernandes and Idris Jala, who have set an example of true leaders who carried in themselves quality leadership. They represented themselves as transformational leaders who bring together the elements of innovative, entrepreneurial, charisma, ethics and transparency in piloting their companies competing in the international market (Tracey \& Hinkin, 1994; Gill et al, 2010). In some instances, the two leaders demonstrated mixed leadership styles depending on the situation in order to implement some changes in the organisation. Therefore, comparison between the leadership styles of these two leaders has led to the conclusion that a leadership style formed depends on the change and situation that happens within the organisation.

In summary, compared to Idris Jala, Tony Fernandes has more freedom in decision making and this made it easier for him to make crucial decision making as the CEO of his organisation. In terms of entrepreneurship skills, Tony Fernades demonstrated extraordinary achievement in expanding his business into other various business portfolios e.g. Tune Hotels, Tune Talk, Tune Sport, Tune Insurance, etc.

Although, during the period as CEO of Malaysia Airlines, Idris Jala was given quite a high percentage of freedom from the government to do the turnaround plans but it was still binding with the Government on any decisions made. This in turn, has limited his actual capability in decision making (Dichter et al, 2008). However, in the history of Malaysia Airlines, he has created a good record as the CEO during his tenure.

All in all, the transactional and transformational leadership theory in the organisation is appearing to be effective in manoeuvring the organisation in the current business scenario. The need for having a leader who has a transformational leadership approach is contributed to the nature of the workforce. Nowadays it is dominated by Genneration $\mathrm{Y}$ whose needs are mentioned in four dimensions of transformational leadership-idealised influence, inspirational motivation, intellectual simulation and individualised consideration.

\section{References}

Atkinson, T. N., \& Pilgreen, T. (2011). Adopting the transformational leadership perspective in a complex research environment. Research Management Review, 18(1), 1-23.

Avolio, B. J., \& Bass, B. M. (2004). Multifactor leadership questionnaire. $3^{\text {rd }}$ edition manual and sampler set. Redwood City, CA: Mind Garden

Bass, B. M. (1990). From transaction to transformational leadership: Learning to share the vision. Organizational Dynamics 18, 19-31. http://dx.doi.org/10.1016/0090-2616(90)90061-S

Bfmudo. (2012). BFM spotlight: Tan Sri Tony Fernandes. Retrieved from $\mathrm{http}: / / \mathrm{www}$.youtube.com/watch?v=zJXHyikqVLU

Cheekypieman. (2008). Mantra of Malaysia Airlines (MAS). Retrieved from http://www.youtube.com/watch?v=LtPj2o8tosk

Christopher, H. (2012). Tony Fernandes - Dream the impossible. Retrieved from http://www.chrisfharvey.com

Christopher, H. (2012). Interview with Tony Fernandes, Founder \& CEO of AirAsia. Retrieved from http://www.youtube.com/watch?v=ibimrMlahec

Desi, A. (2012). Interview with Tony Fernandes. Retrieved from $\mathrm{http}: / / \mathrm{www}$. youtube.com/watch?v=zJ1kwufuilo\&feature=player_detailpage

Deepa, I. (2011). Interview with Idris Jala. Innovation for Successful Societies. Retrieved from www.princeton.edu/successfulsocieties

Dichter, A., Lind, F., \& Singham, S. (2008). Turning around a struggling airline: An interview with the CEO of Malaysia Airlines. The McKingsey Quarterly.

Gill, A., Fitzgerald, S., Bhutani, S., Mand, H., \& Sharma, S. (2008). The relationship between transformational leadership and employee desire for empowerment. International Journal of Contemporary Hospitality Management, 22(2), 263-273. http://dx.doi.org/10.1108/09596111011018223 
Gtproadmap. (2012). Webisode 5: Collective leadership: function like a football team by DS Idris Jala. Retrieved from http://www.youtube.com/watch? $\mathrm{v}=\mathrm{LtPj} 208$ tosk

Holslti, O. (1968). Content analysis. In G.Lindzey \& Aaronson (Eds.), The Handbook of Social Psychology Reading. MA: Addison-Wesley Publishing.

Ismail, S. E. (2010). The rise of Tony Fernandes and AirAsia in Malaysia. Proceeding 18th Biennial Conference of the Asian Studies Association of Australia, Adelaide 5-8 July 2010.

King, A, J, Johnson, D, P., \& Vugt, M. V. (2009). The origins and evolution of leadership. Current Biology, 19, 911-916. http://dx.doi.org/10.1016/j.cub.2009.07.027

Kuhnert, K. W., \& Lewis, P. (1987). Transactional and transformational leadership. A constructive/developmental analysis. Academy of Management Review, 12(4), 648-657.

Malaysia Airlines. (2013). Our History. Retrieved from $\mathrm{http}: / / \mathrm{www} . \mathrm{malaysiaairlines.com/my/en/corporate-info/our-story.html}$

M. A. R., Sarker, C., Hossan G., \& Zaman, L. (2012). Sustainability and growth of Low Cost Airlines: an industry analysis in global perspective. American Journal of Business and Management, 1(3), 162-171.

Man, M. K., \& Justine, J. (2005). AirAsia in the Malaysian domestic airline market: empirical analysis of strategy. International Business \& Economics Research Journal, 4(12), 53-64.

Moore, L., \& Rudd, R. (2006). Leadership style s of current extension leaders. Journal of Agriculture Education, $47(1)$.

Nahavandi, A. (2009). The art and science of leadership (5th ed.). Pearson: New Jersey

Naipul, S., \& Wang, Y. (2009). Entrepreneurship and leadership in hospitality: insights and implications for hospitality and tourism education-Mr. Harris Rosen in conversation with Drs Sandra Naipul and Youcheng Wang. International Journal of Contemporary Hospitality Management, 21(6), 639-658. http://dx.doi.org/10.1108/09596110910975936

Nicholas Ionindes. (2008). Idris Jala: Transforming Malaysia Airlines. Singapore: Airline Business.

Northhouse, P. G. (2004). Leadership: Theory and practice. Thousand Oaks, CA: Sage

O'Connell, J. F., \& William, G. (2005). Passengers' perception of low cost airlines and full service carriers - a case study involving Ryanair, Aer Lingus, Air Asia \& Malaysia Airlines. Journal of Air Transport Management, 11. 259-272. http://dx.doi.org/10.1016/j.jairtraman.2005.01.007

Sutha, P. (2013). Tony Fernandes interview on Nation Channel. Retrieved from http://www.youtube.com/watch?v=yeMgNKzzZT4

Salvation, R. (2006). Enabling transparent leadership: a small business manager's perspective. Journal of Management Development, 25(10), 1018-1020. http://dx.doi.org/10.1108/02621710610708658

Schein, E. H. (2004). Organizational culture and leadership (3rd ed.). (Jossey-Bass, San Francisco).

Siva, G. (2009). Interview: AirAsia CEO Tony Fernandes. Singapore: Airline Business.

Tracey, J. B., \& Hinkin, T. R. (1994). Transformational leaders in the hospitality industry. The Cornell Quarterly.

Wong, K., \& Musa, G. (2011). Branding satisfaction in the airlines industry: A comparative study of Malaysia Airlines and AirAsia. African Journal of Business Management, 5(8), 3410-3423.

Yukl, G. (1989). Managerial leadership: a review. Journal of Management, 15(2). http://dx.doi.org/10.1177/014920638901500207

Zainol, A. Z., \& Romle, A. R. (2007). The truths of service quality (passenger handling) in airlines industry: a descriptive exploration between Malaysia Airlines and AirAsia. Journal of Global Business Management, $3(1)$.

\section{Copyrights}

Copyright for this article is retained by the author(s), with first publication rights granted to the journal.

This is an open-access article distributed under the terms and conditions of the Creative Commons Attribution license (http://creativecommons.org/licenses/by/3.0/). 